\title{
EVALUATION OF SOME EGYPTIAN COTTON GENOTYPES IN THE DELTA USING BOTH COMPRESSED AND COLLECTED LATIN SQUARE DESIGN
}

\author{
(Received:2.5.2011)
}

\author{
By \\ H. A. Idris, S. M. El Tahan and S. S. Badr \\ Cotton Research Institute, Agriculture Research Center, Giza, Egypt.
}

\begin{abstract}
The present investigation dealt with the variances of four Egyptian cotton (Gossypium barbadense L.) genotypes, with respect to yield, its components and fiber properties in the Delta region during 2009 and 2010 seasons. One of the genotypes , cultivar ; G.86 is normally grown in the Delta (control). The others were hybrids (Bulk families), viz. (G.89 x G.86), (G.75 x Sea) and (10229 x G.86). The genotypes were evaluated in the Delta (Sharkia, Dakahlia, Gharbia and Mounofia). Simple latin square design (4 x 4) was used in each experiment. The results exhibited that 10229 x G.86 was the best genotype in the three locations except Dakahlia region since it kept the first rank with respect to yields (seed and lint) and significantly surpassed G.86 in the two seasons. A compressed analysis was used to estimate location and genotype variances. In this research the data of each location (two seasons) considered column and each cell of the design includes eight readings. Statistical analysis of compressed was similar to analysis of simple latin square for more than one observation per experimental unit. A collected analysis was used to estimate locations and genotypes variances due to test one column for fiber properties in each location. Statistical analysis of the collected was similar to analysis of simple latin square with a single determination per plot. The objective of the compressed and the collected was developing simple analysis to use a combined analysis. The compressed surpassed combined since it does not need to calculate homogeneity test of variances (Bartlett test) before the start of analysis. It calculated among locations variances direct through columns, while combined calculated the same value indirect through partitioning locations. It calculated genotypes variance direct, while combined calculated the same value indirect through partitioning genotypes within locations. It gave more information with respect to performance of genotypes under different locations. The collected surpassed combined since it could estimate among locations and genotypes variances using one column of each location. Results of both traditional combined and compressed analysis exhibited that (G.75 x Sea) and (10229 x G.86) significantly surpassed G.86 in yields (seed and lint). 10229 x G.86 was the best genotype with respect to yield components except for boll weight since it kept the first rank and significantly exceeded G.86. Results of collected exhibited that fiber properties were not affected by locations except for strength.
\end{abstract}

Key words: cotton, genotypes, latin square design.

\section{INTRODUCTION}

The subject of the present experiment design has received much attention in recent years. Due to the development of statistical methods, the researcher now has more information than his predecessors as a basis for the solution of problems in the field. It is generally recognized that, by the use of proper designs of experiments and appropriate statistical analysis, all relevant information can be derived from research data. Latin square design layout of an experiment is divided into homogenous blocks in two ways. The blocks in one direction are commonly known as rows and the blocks in the other direction as columns. The number of plots in each row is the same as the number of plots in each column. This number is equal to the number of treatments, (Sing and Narayanan, 2000).

Abou Tour et al. (1996) evaluated five Egyptian cotton cultivars, viz., G.75, G.81, G.85, G.86 and G.89 in three locations in the Delta (El Sharkia, El Gharbia and El Dakahlia). They used latin square design in each location. Results revealed that significant differences due to cultivars were observed with respect to boll weight, seed index, lint percentage, fiber length and micronaire value in the individual locations except for boll weight in El Gharbia and 
micronaire reading in the other two locations. Combined analysis exhibited significant differences for seed index, lint percentage and fiber length. Badr and El Sayed (2004) evaluated five Egyptian cotton genotypes in three locations in the Delta (El Sharkia, El Gharbia and El Mounofia). Genotypes exhibited significant differences with respect to three yield components, viz., boll weight, seed index and lint percentage. On the other hand, the genotypes revealed non-significant differences for seed cotton yield. Idris (2008) evaluated five Egyptian cotton genotypes, viz., G.85, G.86, G.89, (G.89 x G.86) and (G.89 x Pima S-6) in two locations in the Delta (Gharbia and Mounofia) using latin square design. The results exhibited that G.89 x Pima S-6 was the best genotype with respect to yields (seed and lint) since it kept the first rank in the first pick in the two locations and the maturity of this hybrid was faster than other genotypes. G.86 was more skilled with respect to fiber length in the two picks in the two locations. Rahoumah et al. (2008) evaluated 19 cotton genotypes, 2 promising crosses viz., G. 89 x G.86 and G.89 x Pima and 3 cultivars, viz., G.85, G.86 and G.89 in five locations in the Delta. The results revealed significant difference due to locations and genotypes with respect to yield and its components.

Researchers need a statistical measure to evaluate genotypes under different locations. Thus, the objective of the present study was evaluation of some genotypes in different locations to estimate location and genotype variances using the compressed and collected latin square design compared to traditional combined analysis.

\section{MATERIALS AND METHODS}

Four field experiments (4 x 4) latin square design were carried out in four different locations in the Delta region (Sharkia $\left(\mathrm{L}_{1}\right)$, Dakahlia $\left(\mathrm{L}_{2}\right)$, Gharbia $\left(\mathrm{L}_{3}\right)$ and Mounofia $\left(\mathrm{L}_{4}\right)$ ) during 2009 and 2010 seasons. Four long staple Egyptian cotton (Gossypium barbadense L.) genotypes were grown. One of them cultivar G.86 normally grown in the Delta (control). The three remainders were hybrids (Bulk families), viz. (G.89 x G.86), (G.75 x Sea) and (10229 x G.86). Planting was during the last week of March. All other agricultural practices were done as usual.

The genotypes were evaluated for yield, its components and fiber properties. Seed cotton yield (S.C.Y.) in kentar/ feddan and lint cotton yield (L.C.Y.) in kentar/feddan were determined. One sample (50 bolls) was obtained from each plot in all locations to estimate yield components, viz. boll weight (B.W.) in g, lint percentage (L.P.) \%, seed index (S.I.) in $g$ and lint index (L.I) in g. One sample was obtained from each location to estimate fiber properties, viz. fiber length (F.L.) $\mathrm{mm}$, micronaire reading (Mic.) and strength (St.) $\mathrm{g} / \mathrm{tex}$. The lint cotton samples were tested in the Cotton Research Laboratories, Cotton Research Institute using (HVI) equipment.

\subsection{Analysis of simple and combined latin square design}

Analysis of individual locations during the two seasons using simple latin $(4 \mathrm{x} 4)$ was performed to estimate the behavior of genotypes under different locations (Table 1). Analysis of combined latin square was done to estimate locations and genotypes variances.

\subsection{Analysis of compressed and collected latin square design}

A compressed analysis (4 x 4) suggested by the author was used to estimate location and genotype variances for yield and its components (Table 2). In this proposal the data of each location (two seasons) considered column and each cell of the design included eight readings. Statistical analysis of the comprdssed was similar to analysis of simple latin square for more than one observation per experimental unit.

A collected analysis ( $4 \times 4$ ) suggested by the author was used to estimate location and genotype variances due to test one column for fiber properties in each location (Table 3). Statistical analysis of the collected was similar to analysis of simple latin with a single determination per plot.

Statistical analyses of simple, combined, compressed and collected latin square design were straightforward as Cochran and Cox (1950), Federer (1955), Snedecor and Cochran (1967), Little and Hills (1978), Gomez and Gomez (1984) and Roger (1994). The treatment means were compared by L.S.D. test as given by Steel and Torrie (1980). Homogeneity test of variances (Bartlett test) was used according to procedures reported by Bailey (1994). All comparisons were done at 0.05 level of significance.

\section{RESULTS AND DISCUSSION 3.1.Analysis of individual locations.}

The analysis of variance in individual locations using simple analysis during the two seasons with respect to yield and its components revealed the presence of significance columns, rows and genotypes (Table 4).

\subsubsection{Sharkia $\left(\mathbf{L}_{1}\right)$}


Table (1) Layout of simple latin square design in four locations

\begin{tabular}{|c|c|c|c|}
\hline $\mathrm{C}_{1}$ & $\mathrm{~A}_{1}$ & $\mathrm{~B}_{1}$ & $\mathrm{D}_{1}$ \\
$\mathrm{c}_{1}$ & $\mathrm{a}_{1}$ & $\mathrm{~b}_{1}$ & $\mathrm{~d}_{1}$ \\
\hline $\mathrm{B}_{1}$ & $\mathrm{D}_{1}$ & $\mathrm{C}_{1}$ & $\mathrm{~A}_{1}$ \\
$\mathrm{~b}_{1}$ & $\mathrm{~d}_{1}$ & $\mathrm{c}_{1}$ & $\mathrm{a}_{1}$ \\
\hline $\mathrm{A}_{1}$ & $\mathrm{C}_{1}$ & $\mathrm{D}_{1}$ & $\mathrm{~B}_{1}$ \\
$\mathrm{a}_{1}$ & $\mathrm{c}_{1}$ & $\mathrm{~d}_{1}$ & $\mathrm{~b}_{1}$ \\
\hline $\mathrm{D}_{1}$ & $\mathrm{~B}_{1}$ & $\mathrm{~A}_{1}$ & $\mathrm{C}_{1}$ \\
$\mathrm{~d}_{1}$ & $\mathrm{~b}_{1}$ & $\mathrm{a}_{1}$ & $\mathrm{c}_{1}$ \\
\hline
\end{tabular}

$1=$ Sharkia $\left(\mathrm{L}_{1}\right)$

\begin{tabular}{|c|c|c|c|}
\hline $\mathrm{C}_{2}$ & $\mathrm{~A}_{2}$ & $\mathrm{~B}_{2}$ & $\mathrm{D}_{2}$ \\
$\mathrm{c}_{2}$ & $\mathrm{a}_{2}$ & $\mathrm{~b}_{2}$ & $\mathrm{~d}_{2}$ \\
\hline $\mathrm{B}_{2}$ & $\mathrm{D}_{2}$ & $\mathrm{C}_{2}$ & $\mathrm{~A}_{2}$ \\
$\mathrm{~b}_{2}$ & $\mathrm{~d}_{2}$ & $\mathrm{c}_{2}$ & $\mathrm{a}_{2}$ \\
\hline $\mathrm{A}_{2}$ & $\mathrm{C}_{2}$ & $\mathrm{D}_{2}$ & $\mathrm{~B}_{2}$ \\
$\mathrm{a}_{2}$ & $\mathrm{c}_{2}$ & $\mathrm{~d}_{2}$ & $\mathrm{~b}_{2}$ \\
\hline $\mathrm{D}_{2}$ & $\mathrm{~B}_{2}$ & $\mathrm{~A}_{2}$ & $\mathrm{C}_{2}$ \\
$\mathrm{~d}_{2}$ & $\mathrm{~b}_{2}$ & $\mathrm{a}_{2}$ & $\mathrm{c}_{2}$ \\
\hline
\end{tabular}

$2=$ Dakahlia $\left(\mathrm{L}_{2}\right)$

\begin{tabular}{|c|c|c|c|}
\hline $\mathrm{C}_{3}$ & $\mathrm{~A}_{3}$ & $\mathrm{~B}_{3}$ & $\mathrm{D}_{3}$ \\
$\mathrm{c}_{3}$ & $\mathrm{a}_{3}$ & $\mathrm{~b}_{3}$ & $\mathrm{~d}_{3}$ \\
\hline $\mathrm{B}_{3}$ & $\mathrm{D}_{3}$ & $\mathrm{C}_{3}$ & $\mathrm{~A}_{3}$ \\
$\mathrm{~b}_{3}$ & $\mathrm{~d}_{3}$ & $\mathrm{c}_{3}$ & $\mathrm{a}_{3}$ \\
\hline $\mathrm{A}_{3}$ & $\mathrm{C}_{3}$ & $\mathrm{D}_{3}$ & $\mathrm{~B}_{3}$ \\
$\mathrm{a}_{3}$ & $\mathrm{c}_{3}$ & $\mathrm{~d}_{3}$ & $\mathrm{~b}_{3}$ \\
\hline $\mathrm{D}_{3}$ & $\mathrm{~B}_{3}$ & $\mathrm{~A}_{3}$ & $\mathrm{C}_{3}$ \\
$\mathrm{~d}_{3}$ & $\mathrm{~b}_{3}$ & $\mathrm{a}_{3}$ & $\mathrm{c}_{3}$ \\
\hline
\end{tabular}

$3=$ Gharbia $\left(\mathrm{L}_{3}\right)$

A, $a=$ G. $86 \quad$ B , b $=$ G. $89 \times$ G. $86 \quad$ C, $c=$ G. $75 \times$ Sea

\begin{tabular}{|c|c|c|c|}
\hline $\mathrm{C}_{4}$ & $\mathrm{~A}_{4}$ & $\mathrm{~B}_{4}$ & $\mathrm{D}_{4}$ \\
$\mathrm{c}_{4}$ & $\mathrm{a}_{4}$ & $\mathrm{~b}_{4}$ & $\mathrm{~d}_{4}$ \\
\hline $\mathrm{B}_{4}$ & $\mathrm{D}_{4}$ & $\mathrm{C}_{4}$ & $\mathrm{~A}_{4}$ \\
$\mathrm{~b}_{4}$ & $\mathrm{~d}_{4}$ & $\mathrm{c}_{4}$ & $\mathrm{a}_{4}$ \\
\hline $\mathrm{A}_{4}$ & $\mathrm{C}_{4}$ & $\mathrm{D}_{4}$ & $\mathrm{~B}_{4}$ \\
$\mathrm{a}_{4}$ & $\mathrm{c}_{4}$ & $\mathrm{~d}_{4}$ & $\mathrm{~b}_{4}$ \\
\hline $\mathrm{D}_{4}$ & $\mathrm{~B}_{4}$ & $\mathrm{~A}_{4}$ & $\mathrm{C}_{4}$ \\
$\mathrm{~d}_{4}$ & $\mathrm{~b}_{4}$ & $\mathrm{a}_{4}$ & $\mathrm{c}_{4}$ \\
\hline
\end{tabular}

$4=$ Mounofia $\left(\mathrm{L}_{4}\right)$

$\mathrm{D}, \mathrm{d}=10229 \times \mathrm{G} .86$

Capital letter $=$ first season (2009). Small letter $=$ second season (2010).

Table (2) Layout of compressed Latin Square Design

\begin{tabular}{|cccc|cccc|cccc|cccc|}
\hline $\mathrm{C}_{1}$ & $\mathrm{C}_{1}$ & $\mathrm{C}_{1}$ & $\mathrm{C}_{1}$ & $\mathrm{~A}_{2}$ & $\mathrm{~A}_{2}$ & $\mathrm{~A}_{2}$ & $\mathrm{~A}_{2}$ & $\mathrm{~B}_{3}$ & $\mathrm{~B}_{3}$ & $\mathrm{~B}_{3}$ & $\mathrm{~B}_{3}$ & $\mathrm{D}_{4}$ & $\mathrm{D}_{4}$ & $\mathrm{D}_{4}$ & $\mathrm{D}_{4}$ \\
$\mathrm{c}_{1}$ & $\mathrm{c}_{1}$ & $\mathrm{c}_{1}$ & $\mathrm{c}_{1}$ & $\mathrm{a}_{2}$ & $\mathrm{a}_{2}$ & $\mathrm{a}_{2}$ & $\mathrm{a}_{2}$ & $\mathrm{~b}_{3}$ & $\mathrm{~b}_{3}$ & $\mathrm{~b}_{3}$ & $\mathrm{~b}_{3}$ & $\mathrm{~d}_{4}$ & $\mathrm{~d}_{4}$ & $\mathrm{~d}_{4}$ & $\mathrm{~d}_{4}$ \\
\hline $\mathrm{B}_{1}$ & $\mathrm{~B}_{1}$ & $\mathrm{~B}_{1}$ & $\mathrm{~B}_{1}$ & $\mathrm{D}_{2}$ & $\mathrm{D}_{2}$ & $\mathrm{D}_{2}$ & $\mathrm{D}_{2}$ & $\mathrm{C}_{3}$ & $\mathrm{C}_{3}$ & $\mathrm{C}_{3}$ & $\mathrm{C}_{3}$ & $\mathrm{~A}_{4}$ & $\mathrm{~A}_{4}$ & $\mathrm{~A}_{4}$ & $\mathrm{~A}_{4}$ \\
$\mathrm{~b}_{1}$ & $\mathrm{~b}_{1}$ & $\mathrm{~b}_{1}$ & $\mathrm{~b}_{1}$ & $\mathrm{~d}_{2}$ & $\mathrm{~d}_{2}$ & $\mathrm{~d}_{2}$ & $\mathrm{~d}_{2}$ & $\mathrm{c}_{3}$ & $\mathrm{c}_{3}$ & $\mathrm{c}_{3}$ & $\mathrm{c}_{3}$ & $\mathrm{a}_{4}$ & $\mathrm{a}_{4}$ & $\mathrm{a}_{4}$ & $\mathrm{a}_{4}$ \\
\hline $\mathrm{A}_{1}$ & $\mathrm{~A}_{1}$ & $\mathrm{~A}_{1}$ & $\mathrm{~A}_{1}$ & $\mathrm{C}_{2}$ & $\mathrm{C}_{2}$ & $\mathrm{C}_{2}$ & $\mathrm{C}_{2}$ & $\mathrm{D}_{3}$ & $\mathrm{D}_{3}$ & $\mathrm{D}_{3}$ & $\mathrm{D}_{3}$ & $\mathrm{~B}_{4}$ & $\mathrm{~B}_{4}$ & $\mathrm{~B}_{4}$ & $\mathrm{~B}_{4}$ \\
$\mathrm{a}_{1}$ & $\mathrm{a}_{1}$ & $\mathrm{a}_{1}$ & $\mathrm{a}_{1}$ & $\mathrm{c}_{2}$ & $\mathrm{c}_{2}$ & $\mathrm{c}_{2}$ & $\mathrm{c}_{2}$ & $\mathrm{~d}_{3}$ & $\mathrm{~d}_{3}$ & $\mathrm{~d}_{3}$ & $\mathrm{~d}_{3}$ & $\mathrm{~b}_{4}$ & $\mathrm{~b}_{4}$ & $\mathrm{~b}_{4}$ & $\mathrm{~b}_{4}$ \\
\hline $\mathrm{D}_{1}$ & $\mathrm{D}_{1}$ & $\mathrm{D}_{1}$ & $\mathrm{D}_{1}$ & $\mathrm{~B}_{2}$ & $\mathrm{~B}_{2}$ & $\mathrm{~B}_{2}$ & $\mathrm{~B}_{2}$ & $\mathrm{~A}_{3}$ & $\mathrm{~A}_{3}$ & $\mathrm{~A}_{3}$ & $\mathrm{~A}_{3}$ & $\mathrm{C}_{4}$ & $\mathrm{C}_{4}$ & $\mathrm{C}_{4}$ & $\mathrm{C}_{4}$ \\
$\mathrm{~d}_{1}$ & $\mathrm{~d}_{1}$ & $\mathrm{~d}_{1}$ & $\mathrm{~d}_{1}$ & $\mathrm{~b}_{2}$ & $\mathrm{~b}_{2}$ & $\mathrm{~b}_{2}$ & $\mathrm{~b}_{2}$ & $\mathrm{a}_{3}$ & $\mathrm{a}_{3}$ & $\mathrm{a}_{3}$ & $\mathrm{a}_{3}$ & $\mathrm{c}_{4}$ & $\mathrm{c}_{4}$ & $\mathrm{c}_{4}$ & $\mathrm{c}_{4}$ \\
\hline
\end{tabular}

1= Sharkia $\left(\mathrm{L}_{1}\right) \quad 2=$ Dakahlia $\left(\mathrm{L}_{2}\right) \quad 3=$ Gharbia $\left(\mathrm{L}_{3}\right) \quad$ 4=Mounofia $\left(\mathrm{L}_{4}\right)$

A, $a=$ G.86 B , b = G.89 x G.86 C, c = G.75 x Sea $\quad$ D , d = $10229 \times$ G. 86

Capital letter $=$ first season $(2009) . \quad$ Small letter $=$ second season $(2010)$.

Table (3) Layout of collected latin square design

\begin{tabular}{|c|c|c|c|}
\hline $\mathrm{C}_{1}$ & $\mathrm{~A}_{2}$ & $\mathrm{~B}_{3}$ & $\mathrm{D}_{4}$ \\
\hline $\mathrm{B}_{1}$ & $\mathrm{D}_{2}$ & $\mathrm{C}_{3}$ & $\mathrm{~A}_{4}$ \\
\hline $\mathrm{A}_{1}$ & $\mathrm{C}_{2}$ & $\mathrm{D}_{3}$ & $\mathrm{~B}_{4}$ \\
\hline $\mathrm{D}_{1}$ & $\mathrm{~B}_{2}$ & $\mathrm{~A}_{3}$ & $\mathrm{C}_{4}$ \\
\hline
\end{tabular}

1= Sharkia $\left(\mathrm{L}_{1}\right) \quad 2=$ Dakahlia $\left(\mathrm{L}_{2}\right) 3=$ Gharbia $\left(\mathrm{L}_{3}\right) \quad 4=$ Mounofia $\left(\mathrm{L}_{4}\right)$

$\mathrm{A}, \mathrm{a}=\mathrm{G} .86$

B , b $=$ G.89 x G.86

C , c $=$ G.75 x Sea

D , $d=10229$ x G.86

Capital letter $=$ first season $(2009) . \quad$ Small letter $=$ second season $(2010)$. 


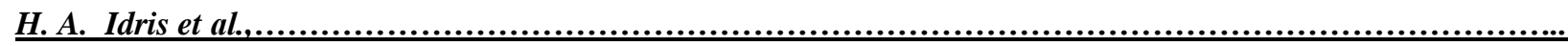

Table (4): Mean squares of yield and its components for individual locations during the first and second seasons using simple latin square.

\begin{tabular}{|c|c|c|c|c|c|c|c|}
\hline \multicolumn{8}{|c|}{ Sharkia $\left(\mathbf{L}_{1}\right)$} \\
\hline \multirow[b]{2}{*}{ Source of variation } & \multirow[b]{2}{*}{ df } & \multicolumn{2}{|c|}{ S. C. Y. (k/fed.) } & \multicolumn{2}{|c|}{ L. C. Y. (k/fed.) } & \multicolumn{2}{|c|}{ B. W. (g) } \\
\hline & & \multicolumn{2}{|r|}{ Second } & First & Second & First & Second \\
\hline Columns & 3 & $1.92 *$ & $0.876^{*}$ & $3.35 * *$ & 1.28 & 0.003 & 0.008 \\
\hline Rows & 3 & $3.11 * *$ & $2.26 * *$ & $4.68 * *$ & $3.07 *$ & 0.005 & $0.045 * *$ \\
\hline Genotypes & 3 & $13.21 * *$ & $3.12 * *$ & $20.72 * *$ & $7.70 * *$ & $0.089 *$ & $0.157 * *$ \\
\hline Experimental error & 6 & 0.268 & 0.094 & 0.331 & 0.332 & 0.017 & 0.003 \\
\hline Source of variation & df & \multicolumn{2}{|c|}{ L. P. (\%) } & \multicolumn{2}{|c|}{ S. I. $(\mathrm{g})$} & \multicolumn{2}{|c|}{ L. I. (g) } \\
\hline Columns & 3 & 0.228 & 0.443 & 0.302 & 0.324 & 0.175 & 0.035 \\
\hline Rows & 3 & 0.029 & 1.09 & 0.752 & $0.666^{*}$ & 0.265 & 0.142 \\
\hline Genotypes & 3 & $5.65 * *$ & $15.72 * *$ & $3.29 * *$ & $1.18 * *$ & $2.91 * *$ & $3.21 * *$ \\
\hline Experimental error & 6 & 0.558 & 0.380 & 0.268 & 0.111 & 0.152 & 0.051 \\
\hline \multicolumn{8}{|c|}{ Dakahlia $\left(\mathbf{L}_{2}\right)$} \\
\hline \multirow[b]{2}{*}{ Source of variation } & \multirow[b]{2}{*}{ df } & \multicolumn{2}{|c|}{ S. C. Y. (k/fed.) } & \multicolumn{2}{|c|}{ L. C. Y. (k/fed.) } & \multicolumn{2}{|c|}{ B. W. (g) } \\
\hline & & First & Second & First & Second & First & Second \\
\hline Columns & 3 & $1.61^{*}$ & 0.189 & 2.12 & 0.361 & 0.003 & 0.013 \\
\hline Rows & 3 & 0.687 & 0.332 & 0.865 & 0.754 & 0.004 & 0.008 \\
\hline Genotypes & 3 & 0.907 & 2.02 & 2.37 & 3.48 & 0.012 & 0.065 \\
\hline Experimental error & 6 & 0.288 & 0.496 & 0.597 & 0.762 & 0.039 & 0.020 \\
\hline Source of variation & df & \multicolumn{2}{|c|}{ L. P. (\%) } & \multicolumn{2}{|c|}{ S. I. (g) } & \multicolumn{2}{|c|}{ L. I. (g) } \\
\hline Columns & 3 & 0.609 & 0.915 & 0.065 & 0.564 & 0.036 & 0.099 \\
\hline Rows & 3 & 0.472 & 0.813 & 0.428 & 0.024 & 0.177 & 0.092 \\
\hline Genotypes & 3 & $5.35 * *$ & $11.21^{* *}$ & 0.750 & $1.85^{*}$ & $1.37 * *$ & $3.08 * *$ \\
\hline Experimental error & 6 & 0.410 & 0.574 & 0.260 & 0.325 & 0.136 & 0.117 \\
\hline & & & Gharb & & & & \\
\hline & & S. C. I & k/fed.) & L. C. & ffed.) & & (g) \\
\hline Source of variation & df & First & Second & First & Second & First & Second \\
\hline Columns & 3 & 0.541 & $4.74 * *$ & 0.808 & $6.78^{* *}$ & 0.010 & 0.007 \\
\hline Rows & 3 & 1.26 & $4.10^{* *}$ & 1.55 & $6.64 * *$ & 0.033 & 0.040 \\
\hline Genotypes & 3 & $1.39^{*}$ & $2.36^{* *}$ & $4.93 * *$ & $6.68^{* *}$ & $0.115^{*}$ & $0.238 * *$ \\
\hline Experimental error & 6 & 0.272 & 0.220 & 0.391 & 0.558 & 0.016 & 0.017 \\
\hline Source of variation & df & L. 1 & & & & & \\
\hline Columns & 3 & 0.019 & 0.324 & 0.046 & $0.326^{*}$ & 0.051 & 0.049 \\
\hline Rows & 3 & 0.412 & 0.027 & $1.43 *$ & 0.071 & 0.696 & 0.051 \\
\hline Genotypes & 3 & $11.74 * *$ & $12.25 * *$ & 1.03 & $2.15^{* *}$ & $2.28^{*}$ & $3.72 * *$ \\
\hline Experimental error & 6 & 0.151 & 0.174 & 0.279 & 0.058 & 0.322 & 0.018 \\
\hline & & & Mour & & & & \\
\hline & & S. C. I & k/fed.) & L. C. & ffed.) & & (g) \\
\hline Source of variation & df & First & Second & First & Second & First & Second \\
\hline Columns & 3 & 0.530 & $9.05^{* * *}$ & 1.08 & $14.84 * *$ & 0.003 & 0.023 \\
\hline Rows & 3 & 1.31 & 1.12 & 1.99 & 1.62 & 0.017 & 0.005 \\
\hline Genotypes & 3 & $2.54 *$ & $3.64 * *$ & $5.50 *$ & $8.15^{* *}$ & 0.055 & 0.013 \\
\hline Experimental error & 6 & 0.341 & 0.346 & 0.625 & 0.430 & 0.022 & 0.020 \\
\hline Source of variation & df & L. 1 & & & & & \\
\hline Columns & 3 & 0.551 & 0.577 & $0.354 *$ & 0.327 & 0.019 & 0.059 \\
\hline Rows & 3 & 0.638 & 0.224 & 0.019 & 0.294 & 0.066 & 0.137 \\
\hline Genotypes & 3 & $6.02 * *$ & $16.57 * *$ & $1.14 * *$ & 0.969 & $1.62 * *$ & $2.20 * *$ \\
\hline Experimental error & 6 & 0.211 & 0.262 & 0.061 & 0.318 & 0.053 & 0.130 \\
\hline
\end{tabular}

$*$, ** Significant at 0.05 and 0.01 levels, respectively. 
In the two seasons, significant variation due to genotypes was observed for yields (seed and lint) and yield components (Table 4). In the first season, hybrids significantly surpassed G.86 with respect to yields (seed and lint). In the second season, 10229 x G.86 significantly exceeded G.86 for yields (seed and lint), while G.75 x Sea significantly surpassed G.86 with respect to seed cotton yield. In the two seasons, 10229 x G.86 significantly exceeded G.86 for yield components except lint percentage and boll weight in the first and second seasons, respectively. The results exhibited that 10229 x G.86 was the best genotype in this location since it kept the first rank with respect to yields (seed and lint), both seed and lint index in the two seasons, boll weight and lint percentage in one season (Table 5).

\subsubsection{Dakahlia $\left(\mathbf{L}_{2}\right)$}

The genotypes exhibited significant differences with respect to seed index in the second season, both for lint percentage and lint index in the two seasons (Table 4). 10229 x G.86 significantly surpassed G.86 for lint index in the two seasons and seed index in the second season. The results exhibited no significant differences among the genotypes with respect to yields (seed and lint) and boll weight in the two seasons and seed index in the first season indicating that performance of both hybrids and G86 were similar in this location (Table 5).

\subsubsection{Gharbia $\left(\mathbf{L}_{3}\right)$}

In the two seasons, significant variation due to genotypes was recorded for yields (seed and lint) and its components except seed index in the first season (Table 4). G.75 x Sea exceeded G.86 for seed cotton yield in the second season. 10229 x G.86 significantly surpassed G.86 for yields (seed and lint) and lint percentage in the two seasons. Both seed and lint index in the second season indicated that it was the best genotype in this location (Table 5).

\subsubsection{Mounofia $\left(\mathbf{L}_{4}\right)$}

Except for seed index in the second season, significant variation due to genotypes was observed for yields (seed and lint), lint percentage, seed and lint index, in the two seasons (Table 4). In both seasons, the hybrids significantly surpassed G.86 with respect to seed cotton yield except G.89 x G.86 in the first season. G.89 x G.86 exceeded G.86 for lint cotton yield in the second season. 10229 x $\quad$ G.86 significantly surpassed G.86 with respect to lint cotton yield and lint index in the two seasons, both seed index and lint percentage in the first and second seasons, respectively. The results exhibited that $10229 \mathrm{x}$ G.86 was the best genotype in this location since it gave the highest values for yields (seed and lint) and lint index in the two seasons (Table 5).

\subsection{Analysis of combined latin square design}

Homogeneity of variance test (Bartlett test) was not significant for yield and its components except lint index.

The analysis of variance showed significant variation due to locations and genotypes (Table 6). Significant difference of locations was observed for yield and its components indicated that yield and its components were highly affected by locations. Significant variations due to partitioning locations into within and among locations were detected for yields (seed and lint) and yield components. Significant variations due to partitioning within locations were observed for yields (seed and lint) and its components in all locations except Sharkia $\left(\mathrm{L}_{1}\right)$ for lint cotton yield and Gharbia $\left(\mathrm{L}_{3}\right)$ for lint percentage and seed index. Significant variations due to partitioning among locations were noticed for yield (seed and lint) and its components except Gharbia $\left(\mathrm{L}_{3}\right)$ vs. Mounofia $\left(\mathrm{L}_{4}\right)$ for lint percentage.

Significant variations due to partitioning genotypes within locations into genotypes and genotypes $\mathrm{x}$ locations were detected for yield (seed and lint) and yield components except seed index for genotypes $x$ locations.

The results of traditional combined analysis exhibited that both (G.75 x Sea) and (10229 x G.86) significantly surpassed G.86 in yields (seed and lint). 10229 x G.86 was the best genotype with respect to yield components since it kept the first rank and significantly exceeded G.86 for lint percentage, both seed and lint index (Table 8).

\subsection{Analysis of compressed latin square design}

The compressed analysis suggested by the author was used (Table 2). In this proposal the data of each location (two seasons) were considered column.

The analysis of variance showed significant variation due to locations and genotypes (Table 7). Significant difference on columns (among locations) was observed for yield and its components indicated that yield and its components were highly affected by locations. Significant variations due to partitioning columns (among locations) were noticed for yields (seed and lint) and its components except $\left(\mathrm{L}_{3}\right)$ vs. $\left(\mathrm{L}_{4}\right)$ for lint percentage and $\left(\mathrm{L}_{1}+\mathrm{L}_{2}\right)$ vs. $\left(\mathrm{L}_{3}+\mathrm{L}_{4}\right)$ for boll weight and seed index. Significant variations due to genotypes were detected for yields (seed 


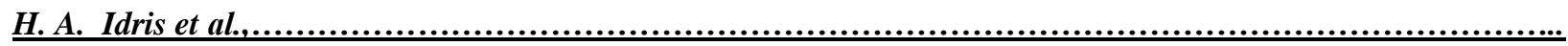

Table (5): Means of yield and its components for individual locations during the two seasons.

\begin{tabular}{|c|c|c|c|c|c|c|}
\hline \multicolumn{7}{|c|}{ Sharkia $\left(L_{1}\right)$} \\
\hline \multirow[b]{2}{*}{ Genotype } & \multicolumn{2}{|c|}{ S. C. Y. (k/fed.) } & \multicolumn{2}{|c|}{ L. C. Y. (k/fed.) } & \multicolumn{2}{|c|}{ B. W. (g) } \\
\hline & First & Second & First & Second & First & Second \\
\hline G.86 & 9.19 & 10.58 & 10.92 & 13.58 & 3.49 & 3.06 \\
\hline G.89 x G.86 & $11.25^{*}$ & 10.00 & $13.01 *$ & 12.36 & 3.43 & 2.70 \\
\hline G.75 x Sea & $12.72 *$ & $11.69^{*}$ & $14.55^{*}$ & 13.86 & 3.50 & 2.71 \\
\hline 10229 x G.86 & $13.25^{*}$ & $11.82 *$ & $16.27 *$ & $15.71^{*}$ & $3.77 *$ & 3.03 \\
\hline L.S.D. & 0.90 & 0.53 & 1.00 & 1.00 & 0.23 & 0.09 \\
\hline Genotype & \multicolumn{2}{|c|}{ L. P. (\%) } & \multicolumn{2}{|c|}{ S. I. (g) } & \multicolumn{2}{|c|}{ L. I. (g) } \\
\hline G.86 & 37.70 & 40.75 & 10.48 & 10.18 & 6.35 & 7.00 \\
\hline G.89 x G.86 & 36.73 & 39.28 & 10.62 & 9.77 & 6.18 & 6.30 \\
\hline G.75 x Sea & 36.30 & 37.65 & 10.93 & 9.68 & 6.23 & 5.87 \\
\hline 10229 x G.86 & 38.97 & $42.28 *$ & $12.45^{*}$ & $10.85^{*}$ & $7.95^{*}$ & $7.93 *$ \\
\hline L.S.D. & 1.29 & 1.07 & 0.90 & 0.58 & 0.68 & 0.39 \\
\hline \multicolumn{7}{|c|}{ Dakahlia $\left(\mathbf{L}_{2}\right)$} \\
\hline Genotype & \multicolumn{2}{|c|}{ S. C. Y. (k/fed.) } & \multicolumn{2}{|c|}{ L. C. Y. (k/fed.) } & \multicolumn{2}{|c|}{ B. W. (g) } \\
\hline G.86 & 8.87 & 9.47 & 11.15 & 12.37 & 2.73 & 2.54 \\
\hline G.89 x G.86 & 8.59 & 10.19 & 10.38 & 12.86 & 2.65 & 2.49 \\
\hline G.75 x Sea & 9.52 & 10.98 & 11.60 & 13.32 & 2.78 & 2.47 \\
\hline 10229 x G.86 & 9.48 & 10.92 & 12.20 & 14.55 & 2.72 & 2.75 \\
\hline L.S.D. & -- & -- & -- & -- & -- & -- \\
\hline Genotype & \multicolumn{2}{|c|}{ L. P. (\%) } & \multicolumn{2}{|c|}{ S. I. (g) } & \multicolumn{2}{|c|}{ L. I. (g) } \\
\hline G.86 & 39.95 & 41.45 & 10.00 & 8.98 & 6.65 & 6.35 \\
\hline G.89 x G.86 & 38.40 & 40.05 & 10.00 & 8.78 & 6.25 & 5.83 \\
\hline G.75 x Sea & 38.70 & 38.50 & 9.75 & 8.80 & 6.18 & 5.50 \\
\hline 10229 x G.86 & 40.90 & 42.33 & 10.75 & $10.20^{*}$ & $7.45^{*}$ & $7.50^{*}$ \\
\hline L.S.D. & 1.11 & 1.31 & -- & 0.99 & 0.64 & 0.59 \\
\hline \multicolumn{7}{|c|}{ Gharbia $\left(\mathrm{L}_{3}\right)$} \\
\hline Genotype & \multicolumn{2}{|c|}{ S. C. Y. (k/fed.) } & \multicolumn{2}{|c|}{ L. C. Y. (k/fed.) } & \multicolumn{2}{|c|}{ B. W. (g) } \\
\hline G.86 & 8.56 & 10.54 & 10.86 & 13.35 & 3.05 & 3.01 \\
\hline G.89 x G.86 & 9.22 & 10.60 & 11.23 & 13.16 & 2.66 & 2.49 \\
\hline G.75 x Sea & 8.27 & $11.53^{*}$ & 9.86 & 13.78 & 2.91 & 2.69 \\
\hline 10229 x G.86 & $9.55^{*}$ & $12.00^{*}$ & $12.54 *$ & $15.96^{*}$ & 2.97 & 2.96 \\
\hline L.S.D. & 0.90 & 0.81 & 1.08 & 1.29 & 0.22 & 0.23 \\
\hline Genotype & & & & & & \\
\hline G.86 & 40.33 & 40.25 & 10.23 & 10.40 & 6.92 & 7.00 \\
\hline G.89 x G.86 & 38.70 & 39.45 & 9.48 & 9.32 & 5.90 & 6.05 \\
\hline G.75 x Sea & 37.85 & 37.97 & 9.82 & 9.90 & 5.97 & 6.05 \\
\hline 10229 x G.86 & $41.70^{*}$ & $42.18^{*}$ & 10.65 & $11.05^{*}$ & 7.63 & $8.07 *$ \\
\hline L.S.D. & 0.67 & 0.72 & -- & 0.42 & 0.98 & 0.23 \\
\hline & & & iia $\left(L_{4}\right)$ & & & \\
\hline Genotype & S. C & fed.) & L. C & fed.) & & \\
\hline G.86 & 11.18 & 5.53 & 14.11 & 7.14 & 3.20 & 2.85 \\
\hline G.89 x G.86 & 11.40 & $6.62 *$ & 13.93 & $8.40 *$ & 3.16 & 2.90 \\
\hline G.75 x Sea & $12.25^{*}$ & $6.91 *$ & 14.60 & 8.24 & 3.36 & 2.96 \\
\hline 10229 x G.86 & $12.91 *$ & $7.84 *$ & $16.49 *$ & $10.55^{*}$ & 3.39 & 2.97 \\
\hline L.S.D. & 1.01 & 1.02 & 1.37 & 1.14 & -- & -- \\
\hline Genotype & & & & & & \\
\hline G.86 & 40.05 & 41.08 & 10.32 & 10.00 & 6.93 & 6.95 \\
\hline G.89 x G.86 & 38.83 & 40.25 & 10.68 & 9.95 & 6.82 & 6.70 \\
\hline G.75 x Sea & 37.85 & 37.78 & 10.42 & 10.65 & 6.33 & 6.45 \\
\hline 10229 x G.86 & 40.58 & $42.65^{*}$ & $11.50 *$ & 10.95 & $7.85^{*}$ & $8.13^{*}$ \\
\hline L.S.D. & 0.80 & 0.89 & 0.43 & -- & 0.40 & 0.62 \\
\hline
\end{tabular}

-- : Not significant at 0.05 level. * , Hybrids significantly surpassed G.86 (control) 
Table (6): Mean squares of yield and its components for combined latin square.

\begin{tabular}{|c|c|c|c|c|}
\hline Source of variation & df & S. C. Y. (k/fed.) & L. C. Y. (k/fed.) & B. W. (g) \\
\hline Locations (L) & 7 & $49.12 * *$ & $68.83 * *$ & $1.62 * *$ \\
\hline Within locations & 4 & $68.42 * *$ & $101.81 * *$ & $1.25 * *$ \\
\hline Sharkia $\left(\mathbf{L}_{1}\right)$ & 1 & $2.67 * *$ & 0.290 & $3.65 * *$ \\
\hline Dakahlia $\left(\mathbf{L}_{2}\right)$ & 1 & $13.06^{* *}$ & $30.07 * *$ & $0.200 * *$ \\
\hline Gharbia $\left(\mathbf{L}_{3}\right)$ & 1 & $41.07 * *$ & $69.06^{* *}$ & $0.100 * *$ \\
\hline Mounofia $\left(\mathbf{L}_{4}\right)$ & 1 & $216.89 * *$ & $307.83^{* *}$ & $1.03 * *$ \\
\hline Among locations & 3 & $23.38^{* *}$ & $24.85^{* *}$ & $2.11 * *$ \\
\hline $\mathbf{L}_{1}$ VS. $\mathbf{L}_{2}$ & 1 & $38.98 * *$ & $35.00^{* *}$ & $5.22 * *$ \\
\hline $\mathbf{L}_{3}$ VS. $\mathbf{L}_{4}$ & 1 & $7.95^{* *}$ & $13.30^{* * *}$ & $1.05^{* *}$ \\
\hline $\mathbf{L}_{1}+\mathbf{L}_{2}$ VS. $\mathbf{L}_{3}+\mathbf{L}_{4}$ & 1 & $23.21 * *$ & $26.26^{* *}$ & $0.064^{*}$ \\
\hline Columns within (L) & 24 & \multirow{7}{*}{$\begin{array}{l}2.43^{* *} \\
1.77^{* *} \\
3.65^{* *} \\
19.02^{* *} \\
1.45^{* *} \\
0.290^{4}\end{array}$} & \multirow{7}{*}{$\begin{array}{l}3.82^{* *} \\
2.65 * * \\
7.44^{* *} \\
44.37 * * \\
2.16^{* *} \\
0.565\end{array}$} & \multirow{7}{*}{$\begin{array}{l}0.009 \\
0.020 \\
0.093 * * \\
0.390 * * \\
0.050 * * \\
0.019\end{array}$} \\
\hline Rows within (L) & 24 & & & \\
\hline Genotypes within (L) & 24 & & & \\
\hline Genotypes $(\mathbf{G})$ & 3 & & & \\
\hline G X L & 21 & & & \\
\hline Experimental error & 48 & & & \\
\hline Total & 127 & & & \\
\hline Source of variation & df & L.P. (\%) & S. I. (g) & L. I. (g) \\
\hline Locations (L) & 7 & $15.65 * *$ & $5.06 * *$ & -- \\
\hline Within locations & 4 & $18.20 * *$ & $4.03 * *$ & -- \\
\hline Sharkia $\left(L_{1}\right)$ & 1 & $52.53 * *$ & $8.00 * *$ & -- \\
\hline Dakahlia $\left(\mathbf{L}_{2}\right)$ & 1 & $9.57 * *$ & $7.03 * *$ & -- \\
\hline Gharbia $\left(\mathbf{L}_{3}\right)$ & 1 & 0.810 & 0.130 & -- \\
\hline Mounofia $\left(\mathbf{L}_{4}\right)$ & 1 & $9.90 * *$ & $0.950 *$ & -- \\
\hline Among locations & 3 & $11.81 * *$ & $6.44 * *$ & -- \\
\hline$L_{1}$ vS. $L_{2}$ & 1 & $28.23 * *$ & $14.82 * *$ & -- \\
\hline $\mathbf{L}_{3}$ VS. $\mathbf{L}_{4}$ & 1 & 0.091 & $3.29 * *$ & -- \\
\hline $\mathbf{L}_{1}+\mathrm{L}_{2}$ vs. $\mathrm{L}_{3}+\mathrm{L}_{4}$ & 1 & $7.12 * *$ & $1.22 * *$ & -- \\
\hline Columns within $(\mathrm{L})$ & 24 & 0.458 & 0.289 & -- \\
\hline Rows within (L) & 24 & 0.463 & $0.460 *$ & -- \\
\hline Genotypes within (L) & 24 & $10.56 * *$ & $1.54 * *$ & -- \\
\hline Genotypes (G) & 3 & $78.12 * *$ & $9.78 * *$ & -- \\
\hline $\mathbf{G} \times \mathbf{L}$ & 21 & $0.910^{* *}$ & 0.362 & -- \\
\hline Experimental error & 48 & 0.340 & 0.210 & -- \\
\hline Total & 127 & & & -- \\
\hline
\end{tabular}

--, not combined analysis due to Bartlett test was significant.

*, ** Significant at 0.05 and 0.01 levels, respectively.

and lint) and its components.

The compressed calculated genotypes variance in different seasons (between readings on the same sample) and gave more information with respect to performance of genotypes under different locations.

First partitioning in $\left(\mathrm{L}_{1}+\mathrm{L}_{2}+\mathrm{L}_{3}+\mathrm{L}_{4}\right)$, G.89 x G.86 surpassed G.86 with respect to seed cotton yield sine it had the lowest values of variance. The results explain that this hybrid was slightly affected by different environments for yields.
Results exhibited that hybrids exceeded G.86 with respect to lint cotton yield, lint percentage and lint index except 10229 x G.86 for lint percentage. On contrast, G.86 had the lowest values of variance than hybrids with respect to yield component viz., boll weight and seed index.

Second partitioning in $\left(\mathrm{L}_{1}+\mathrm{L}_{2}\right)$, results showed that the hybrids exceeded G.86 for lint cotton yield, lint percentage and lint index except 10229 x G.86 with respect to lint percentage due to their lowest values of variance. On contrast, 


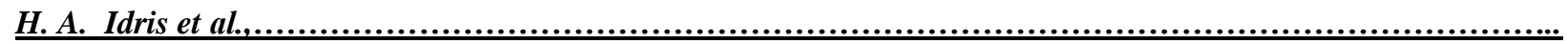

Table (7): Mean squares of yield and its components for the compressed latin square.

\begin{tabular}{|c|c|c|c|c|}
\hline Source of variation & df & S. C. Y. (k/fed.) & L. C. Y. (k/fed.) & B. W. (g) \\
\hline Columns (among locations) & 3 & $23.38 * *$ & $24.85 * *$ & $2.11 * *$ \\
\hline$\left(\mathbf{L}_{1}\right)$ vs. $\left(\mathbf{L}_{2}\right)$ & 1 & $38.98^{* *}$ & $35.00^{* *}$ & $5.22 * *$ \\
\hline$\left(\mathbf{L}_{3}\right)$ vs. $\left(\mathbf{L}_{4}\right)$ & 1 & $7.95^{*}$ & $13.30 *$ & $1.05^{* *}$ \\
\hline$\left(L_{1}+L_{2}\right)$ vs. $\left(L_{3}+L_{4}\right)$ & 1 & $23.21 * *$ & $26.26^{* *}$ & 0.064 \\
\hline 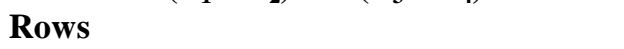 & 3 & 2.68 & 3.91 & $0.178 *$ \\
\hline Genotypes & 3 & $19.02 * *$ & $44.37 * *$ & $0.390 * *$ \\
\hline Experimental error & 6 & 0.834 & 1.38 & 0.026 \\
\hline Among samples within cells & 32 & 2.39 & 3.81 & 0.021 \\
\hline Among samples in columns & 8 & 3.73 & 5.59 & 0.021 \\
\hline Remainder & 24 & 1.94 & 3.22 & 0.022 \\
\hline Between reading on the same sample & 64 & 5.15 & 7.66 & 0.098 \\
\hline $\mathbf{G . 8 6}\left(\mathbf{L}_{1}+\underset{L_{2}}{\mathbf{L}_{2}} \mathbf{L}_{3}+\mathbf{L}_{4}\right)$ & 16 & 5.08 & 8.40 & 0.063 \\
\hline $\begin{array}{ll}\left(\mathbf{L}_{1}+\mathbf{L}_{2}\right) & \left(\mathbf{L}_{1}\right)\end{array}$ & 4 & $\begin{array}{r}0.154 \\
1.29\end{array}$ & $\begin{array}{l}2.50 \\
4.08\end{array}$ & $\begin{array}{l}0.0 / 4 \\
0.110\end{array}$ \\
\hline$\left(\mathbf{L}_{2}\right)$ & 4 & 0.221 & 0.916 & 0.038 \\
\hline$\left(\mathbf{L}_{3}+\mathbf{L}_{4}\right)$ & 8 & 9.40 & 14.30 & 0.051 \\
\hline$\left(\mathbf{L}_{3}\right)$ & 4 & 2.58 & 3.90 & 0.009 \\
\hline$\left(\mathbf{L}_{4}\right)$ & 4 & 16.23 & 24.70 & 0.094 \\
\hline G.89 x G.86( $\left(L_{1}+L_{2}+L_{3}+L_{4}\right)$ & 16 & 4.64 & 6.47 & 0.094 \\
\hline$\left(\mathbf{L}_{1}+\mathbf{L}_{2}\right)$ & 8 & 1.24 & 1.89 & 0.074 \\
\hline$\left(\mathbf{L}_{1}\right)$ & 4 & 0.980 & 0.405 & 0.274 \\
\hline$\left(\mathbf{L}_{2}\right)$ & 4 & 1.50 & 3.37 & 0.015 \\
\hline$\left(\mathbf{L}_{3}+\mathbf{L}_{4}\right)$ & 8 & 8.03 & 11.05 & 0.043 \\
\hline$\left(\mathbf{L}_{3}\right)$ & 4 & 4.01 & 5.83 & 0.043 \\
\hline$\left(\mathbf{L}_{4}\right)$ & 4 & 12.05 & 16.28 & 0.042 \\
\hline G.75 x Sea $\left(L_{1}+L_{2}+L_{3}+L_{4}\right)$ & 16 & 5.70 & 7.93 & 0.125 \\
\hline$\left(\mathbf{L}_{1}+\mathbf{L}_{2}\right)$ & 8 & 1.03 & 1.13 & 0.190 \\
\hline$\left(\mathbf{L}_{1}\right)$ & 4 & 0.910 & 0.724 & 0.324 \\
\hline$\left(\mathbf{L}_{2}\right)$ & 4 & 1.15 & 1.55 & 0.056 \\
\hline$\left(\mathbf{L}_{3}+\mathbf{L}_{4}\right)$ & 8 & 10.37 & 14.73 & 0.060 \\
\hline$\left(\mathbf{L}_{3}\right)$ & 4 & 5.66 & 8.20 & 0.027 \\
\hline$\left(\mathbf{L}_{4}\right)$ & 4 & 15.08 & 21.25 & 0.094 \\
\hline $10229 \times G .86\left(L_{1}+L_{2}+L_{3}+L_{4}\right)$ & 16 & 5.19 & 7.82 & 0.111 \\
\hline$\left(\mathbf{L}_{1}+\mathbf{L}_{2}\right)$ & 8 & 1.66 & 2.39 & 0.151 \\
\hline$\left(\mathbf{L}_{1}\right)$ & 4 & 1.35 & 0.740 & 0.286 \\
\hline$\left(\mathbf{L}_{2}\right)$ & 4 & 1.97 & 4.04 & 0.016 \\
\hline$\left(\mathbf{L}_{3}+\mathbf{L}_{4}\right)$ & 8 & 8.73 & 13.26 & 0.071 \\
\hline$\left(\mathbf{L}_{3}\right)$ & 4 & 3.86 & 7.45 & 0.050 \\
\hline$\left(\mathbf{L}_{4}\right)$ & 4 & 13.59 & 19.06 & 0.091 \\
\hline Total & 111 & & & \\
\hline
\end{tabular}


Table (7) Cont.

\begin{tabular}{|c|c|c|c|c|}
\hline Source of variation & df & L.P. (\%) & S. I. (g) & L. I. (g) \\
\hline Columns (among locations) & 3 & $11.81^{* *}$ & $6.44 * *$ & $1.66^{* * *}$ \\
\hline$\left(\mathbf{L}_{1}\right)$ vs. $\left(\mathbf{L}_{2}\right)$ & 1 & $28.23^{* *}$ & $14.82^{* *}$ & $1.10^{*}$ \\
\hline$\left(\mathbf{L}_{3}\right)$ vs. $\left(\mathbf{L}_{4}\right)$ & 1 & 0.091 & $3.29 * *$ & $1.63 *$ \\
\hline$\left(\mathbf{L}_{1}+\mathbf{L}_{2}\right)$ vs. $\left(\mathbf{L}_{3}+\mathbf{L}_{4}\right)$ & 1 & $7.12 * *$ & 1.22 & $2.26 * *$ \\
\hline Rows & 3 & 0.734 & 0.844 & 0.292 \\
\hline Genotypes & 3 & $78.12 * *$ & $9.78 * *$ & $19.56^{* *}$ \\
\hline Experimental error & 6 & 0.370 & 0.232 & 0.157 \\
\hline Among samples within cells & 32 & 0.656 & 0.455 & 0.173 \\
\hline Among samples in columns & 8 & 0.634 & 0.757 & $0.335^{*}$ \\
\hline Remainder & 24 & 0.664 & 0.355 & 0.119 \\
\hline Between reading on the same sample & 64 & 1.64 & 0.520 & 0.135 \\
\hline $\begin{array}{c}\mathbf{G . 8 6}\left(\mathbf{L}_{1}+\mathbf{L}_{2}+\mathbf{L}_{3}+\mathbf{L}_{4}\right) \\
\left(\mathbf{L}_{1}+\mathbf{L}_{2}\right)\end{array}$ & 16 & $\begin{array}{ll}2.00 & \\
& 3.50\end{array}$ & $\begin{array}{l}0.315 \\
0.427\end{array}$ & $\begin{array}{l}0.167 \\
0.280\end{array}$ \\
\hline$\left(\mathbf{L}_{1}\right)$ & 4 & 5.06 & 0.303 & 0.437 \\
\hline$\left(\mathbf{L}_{2}\right)$ & 4 & 1.94 & 0.551 & 0.122 \\
\hline$\left(\mathbf{L}_{3}+\mathbf{L}_{4}\right)$ & 8 & 0.505 & 0.203 & 0.054 \\
\hline$\left(\mathbf{L}_{3}\right)$ & 4 & 0.124 & 0.034 & 0.014 \\
\hline$\left(\mathbf{L}_{4}\right)$ & 4 & 0.886 & 0.371 & 0.094 \\
\hline G.89 x G.86 $\left(L_{1}+L_{2}+L_{3}+L_{4}\right)$ & 16 & 1.75 & 0.722 & 0.143 \\
\hline$\left(\mathbf{L}_{1}+\mathbf{L}_{2}\right)$ & 8 & 2.68 & 0.857 & 0.116 \\
\hline$\left(\mathbf{L}_{1}\right)$ & 4 & 3.64 & 0.673 & 0.089 \\
\hline$\left(\mathbf{L}_{2}\right)$ & 4 & 1.71 & 1.04 & 0.144 \\
\hline$\left(\mathbf{L}_{3}+\mathbf{L}_{4}\right)$ & 8 & 0.821 & 0.587 & 0.171 \\
\hline$\left(\mathbf{L}_{3}\right)$ & 4 & 0.602 & 0.795 & 0.295 \\
\hline$\left(\mathbf{L}_{4}\right)$ & 4 & 1.04 & 0.379 & 0.046 \\
\hline G.75 x Sea $\left(L_{1}+L_{2}+L_{3}+L_{4}\right)$ & 16 & 0.407 & 0.549 & 0.150 \\
\hline$\left(\mathbf{L}_{1}+\mathbf{L}_{2}\right)$ & 8 & 0.700 & 0.886 & 0.231 \\
\hline$\left(\mathbf{L}_{1}\right)$ & 4 & 1.10 & 1.15 & 0.187 \\
\hline$\left(\mathbf{L}_{2}\right)$ & 4 & 0.297 & 0.625 & 0.274 \\
\hline$\left(\mathbf{L}_{3}+\mathbf{L}_{4}\right)$ & 8 & 0.114 & 0.211 & 0.070 \\
\hline$\left(\mathbf{L}_{3}\right)$ & 4 & 0.044 & 0.216 & 0.074 \\
\hline$\left(\mathbf{L}_{4}\right)$ & 4 & 0.184 & 0.206 & 0.066 \\
\hline $10229 \times$ G.86 $\left(L_{1}+L_{2}+L_{3}+L_{4}\right)$ & 16 & 2.40 & 0.493 & 0.079 \\
\hline$\left(\mathbf{L}_{1}+\mathbf{L}_{2}\right)$ & 8 & 3.50 & 0.800 & 0.023 \\
\hline$\left(\mathbf{L}_{1}\right)$ & 4 & 5.66 & 1.40 & 0.024 \\
\hline$\left(\mathbf{L}_{2}\right)$ & 4 & 1.35 & 0.203 & 0.022 \\
\hline$\left(\mathbf{L}_{3}+\mathbf{L}_{4}\right)$ & 8 & 1.30 & 0.186 & 0.134 \\
\hline$\left(\mathbf{L}_{3}\right)$ & 4 & 0.169 & 0.148 & 0.163 \\
\hline$\left(\mathbf{L}_{4}\right)$ & 4 & 2.43 & 0.225 & 0.106 \\
\hline Total & 111 & & & \\
\hline
\end{tabular}




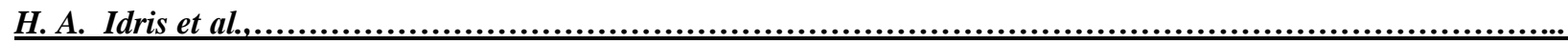

Table (8): Means of locations and genotypes (yield and its components) for combined and compressed latin square analysis.

\begin{tabular}{|c|c|c|c|c|c|c|}
\hline \multicolumn{7}{|c|}{ Traits } \\
\hline \multirow[b]{2}{*}{ Locations } & \multicolumn{3}{|c|}{ S. C. Y. (k/fed.) } & \multicolumn{3}{|c|}{ L. C. Y. (k/fed.) } \\
\hline & \multicolumn{2}{|c|}{ Combined } & compressed & \multicolumn{2}{|c|}{ Combined } & compressed \\
\hline Sharkia $\left(L_{1}\right)$ & 11.60 & 11.02 & 11.31 & 13.69 & 13.88 & 13.78 \\
\hline Dakahlia $\left(\mathbf{L}_{2}\right)$ & 9.11 & 10.39 & 9.75 & 11.33 & 13.27 & 12.30 \\
\hline Gharbia $\left(\mathbf{L}_{3}\right)$ & 8.90 & 11.16 & 10.03 & 11.12 & 14.06 & 12.59 \\
\hline Mounofia $\left(\mathbf{L}_{4}\right)$ & 11.93 & 6.72 & 9.33 & 14.78 & 8.58 & 11.68 \\
\hline L.S.D. & \multicolumn{2}{|c|}{0.54} & 0.56 & \multicolumn{2}{|c|}{0.76} & 0.72 \\
\hline & \multicolumn{3}{|c|}{ B. W. (g) } & \multicolumn{3}{|c|}{ L. P. (\%) } \\
\hline Locations & \multicolumn{2}{|c|}{ Combined } & compressed & \multicolumn{2}{|c|}{ Combined } & compressed \\
\hline Sharkia $\left(L_{1}\right)$ & 3.55 & 2.87 & 3.21 & 37.43 & 39.99 & 38.71 \\
\hline Dakahlia $\left(\mathbf{L}_{2}\right)$ & 2.72 & 2.56 & 2.64 & 39.49 & 40.58 & 40.03 \\
\hline Gharbia $\left(\mathbf{L}_{3}\right)$ & 2.90 & 2.79 & 2.84 & 39.64 & 39.96 & 39.80 \\
\hline $\operatorname{Mounofia}\left(\mathbf{L}_{4}\right)$ & 3.28 & 2.92 & 3.10 & 39.33 & 40.44 & 39.88 \\
\hline L.S.D. & \multicolumn{2}{|c|}{0.14} & 0.10 & \multicolumn{2}{|c|}{0.59} & 0.37 \\
\hline & \multicolumn{3}{|c|}{ S. I. (g) } & \multicolumn{3}{|c|}{ L. I. (g) } \\
\hline Locations & \multicolumn{2}{|c|}{ Combined } & compressed & \multicolumn{2}{|c|}{ Combined } & compressed \\
\hline Sharkia $\left(L_{1}\right)$ & 11.12 & 10.12 & 10.62 & -- & -- & 6.73 \\
\hline Dakahlia $\left(\mathbf{L}_{2}\right)$ & 10.13 & 9.19 & 9.66 & -- & -- & 6.46 \\
\hline Gharbia $\left(\mathbf{L}_{3}\right)$ & 10.04 & 10.17 & 10.11 & -- & -- & 6.70 \\
\hline $\operatorname{Mounofia}\left(\mathbf{L}_{4}\right)$ & 10.73 & 10.39 & 10.56 & -- & -- & 7.02 \\
\hline L.S.D. & \multicolumn{2}{|c|}{0.46} & 0.30 & & & 0.24 \\
\hline \multicolumn{7}{|c|}{ Traits } \\
\hline Genotypes & $\begin{array}{l}\text { S. C. Y. } \\
\text { (k/fed.) }\end{array}$ & $\begin{array}{l}\text { L. C. Y. } \\
\text { (k/fed.) }\end{array}$ & $\begin{array}{c}\text { B. W. } \\
(\mathrm{g})\end{array}$ & $\begin{array}{c}\text { L. P. } \\
(\%)\end{array}$ & $\begin{array}{c}\text { S. I. } \\
\text { (g) }\end{array}$ & $\begin{array}{c}\text { L. I. } \\
\text { (g) }\end{array}$ \\
\hline G.86 & 9.24 & 11.68 & 2.99 & 40.19 & 10.07 & 6.77 \\
\hline G.89 x G.86 & 9.73 & 11.92 & 2.81 & 38.96 & 9.82 & 6.25 \\
\hline G.75 x Sea & $10.48 *$ & $12.48^{*}$ & 2.92 & 37.83 & 9.99 & 6.07 \\
\hline 10229 x G.86 & $10.97 *$ & $14.28 *$ & 3.07 & $41.45^{*}$ & $11.05 *$ & $7.81 *$ \\
\hline L.S.D. combined & 0.54 & 0.76 & 0.14 & 0.59 & 0.46 & -- \\
\hline L.S.D. compressed & 0.56 & 0.72 & 0.10 & 0.37 & 0.30 & 0.24 \\
\hline
\end{tabular}

--, not combined analysis due to Bartlett test was significant. * , Hybrids significantly surpassed G.86 (control).

Table (9): Mean squares of fiber properties for collected latin square.

\begin{tabular}{|c|c|c|c|c|c|c|c|}
\hline \multirow[b]{2}{*}{ Source of variation } & \multirow[b]{2}{*}{ df } & \multicolumn{2}{|c|}{ F. L. (mm) } & \multicolumn{2}{|c|}{ Mic. } & \multicolumn{2}{|c|}{ St. (g/tex) } \\
\hline & & First & Second & First & Second & First & Second \\
\hline Columns (locations) & 3 & 0.184 & 0.910 & 0.016 & 0.014 & $16.81 * *$ & 9.44 \\
\hline Rows & 3 & 0.104 & 0.109 & 0.002 & 0.002 & 2.23 & 6.60 \\
\hline Genotypes & 3 & $3.43 * *$ & 0.329 & $0.492 * *$ & 0.032 & $14.12 * *$ & 3.85 \\
\hline Experimental error & 6 & 0.128 & 0.329 & 0.011 & 0.008 & 1.30 & 3.52 \\
\hline
\end{tabular}

* , ** Significant at 0.05 and 0.01 levels, respectively.

Table (10): Means of locations and genotypes (fiber properties) for the collected latin square.

\begin{tabular}{|c|c|c|c|c|c|c|}
\hline \multicolumn{7}{|c|}{ Traits } \\
\hline \multirow[b]{2}{*}{ Locations (columns) } & \multicolumn{2}{|c|}{ F. L. (mm) } & \multicolumn{2}{|c|}{ Mic. } & \multicolumn{2}{|c|}{ St. (g/tex) } \\
\hline & First & Second & First & Second & First & Second \\
\hline Sharkia $\left(\mathrm{L}_{1}\right)$ & 33.20 & 33.48 & 4.05 & 4.13 & 40.83 & 43.35 \\
\hline Dakahlia $\left(\mathbf{L}_{2}\right)$ & 33.55 & 32.98 & 4.13 & 4.13 & 44.30 & 44.68 \\
\hline Gharbia $\left(\mathbf{L}_{3}\right)$ & 33.13 & 33.38 & 4.15 & 4.25 & 41.40 & 44.47 \\
\hline $\operatorname{Mounofia}\left(\mathbf{L}_{4}\right)$ & 33.08 & 32.43 & 4.20 & 4.18 & 39.43 & 41.33 \\
\hline L.S.D. & -- & -- & -- & -- & 1.97 & -- \\
\hline \multicolumn{7}{|l|}{ Genotypes } \\
\hline G.86 & 32.83 & 33.10 & 4.48 & 4.25 & 42.20 & 44.70 \\
\hline G.89 x G.86 & 32.37 & 32.65 & 4.35 & 4.23 & 43.43 & 43.75 \\
\hline G.75 x Sea & 33.23 & 33.30 & 3.70 & 4.05 & 38.98 & 42.50 \\
\hline 10229 x G.86 & $34.53 *$ & 33.20 & 4.00 & 4.15 & 41.35 & 42.88 \\
\hline L.S.D. & 0.62 & -- & 0.18 & -- & 1.97 & -- \\
\hline
\end{tabular}


G.86 had the lowest values of variance than hybrids for seed cotton yield and seed index. Both G.89 x G.86 and 10229 x G.86 were similar to G.86 for boll weight and lint percentage, respectively.

In $\left(\mathrm{L}_{3}+\mathrm{L}_{4}\right)$, except $\mathrm{G} .75 \times$ x Sea hybrids surpassed G.86 with respect to yields (seed and lint) due to their lowest values of variance. G. $89 \mathrm{x}$ G.86, G.75 x Sea and 10229 x G.86 had the lowest values of variance than G.86 for boll weight, lint percentage and seed index, respectively. G.86 had the lowest values of variance than hybrids with respect to lint index.

Third partitioning in $\left(\mathrm{L}_{1}\right)$, hybrids surpassed G.86 with respect to yields (seed and lint), lint percentage and lint index due to their lowest values of variance except 10229 x G.86 for seed cotton yield and lint percentage. G.86 gave the lowest value for boll weight and seed index.

In $\left(\mathrm{L}_{2}\right)$, the results exhibited that G.86 exceeded hybrids with respect to yields (seed and lint) because of their lowest variance in different seasons. Except G.75 x Sea for boll weight, hybrids surpassed G.86 for boll weight and lint percentage. 10229 x G.86 had the lowest values of variance than G.86 with respect to seed index and lint index.

In $\left(\mathrm{L}_{3}\right), \mathrm{G} .86$ surpassed hybrids with respect to yields (seed and lint) and its components due to having the lowest variance in different seasons except G.75 x Sea for lint percentage.

In $\left(\mathrm{L}_{4}\right)$, hybrids exceeded G.86 with respect to yields (seed and lint), seed index and lint index due to having lowest variance in different seasons except G.89 x G.86 and 10229 x G.86 for seed index and lint index, respectively. G.89 x G.86 and G.75 x Sea gave the lowest variance than G.86 for boll weight and lint percentage, respectively.

The results of compressed analysis exhibited that (G.75 x Sea) and (10229 x G.86) significantly surpassed G.86 in yields (seed and lint). $10229 \mathrm{x}$ G.86 was the best genotype with respect to yield components, viz. lint percentage, seed index and lint index since it kept the first rank and significantly exceeded G.86 (Table 8).

\subsection{Analysis of collected latin square design}

The collected analysis suggested by the author was used (Table 3). The objective of the collected (columns) was to develop simple analysis to use a combined analysis.

The analysis of variance showed significant variation due to columns (locations) and genotypes with respect to fiber properties (Table 9).
Significant difference due to columns (locations) was observed for strength in the first season. Results exhibited that fiber properties were not affected by locations. A significant variation due to genotypes was detected for fiber length, micronaire reading and strength in the first season. Also in the first season, 10229 x G.86 significantly surpassed G.86 with respect to fiber length (Table 10).

\subsection{Comparisons among compressed, collected and combined latin square design}

The objective of both the compressed and the collected was to develop simple analysis to use a combined analysis. They used the same degree of freedom of simple with respect to columns, rows, genotypes and experimental error.

The compressed depends on reducing number of columns, rows and experimental error. In contrast, combined depends on increasing number of columns, rows and experimental error.

The compressed surpassed combined since it does not need to calculate homogeneity test of variances (Bartlett test) before the start of analysis.

The compressed surpassed combined due to it calculated among locations variances direct through columns, while combined calculated the same value indirect through partitioning locations. It calculated genotypes variance direct, while combined calculated the same value indirect through partitioning genotypes within locations.

The compressed surpassed combined for calculated genotypes variance in different seasons (between reading on the same sample) and gave more information with respect to performance of genotypes under different locations.

Although the two ways of analyses (compressed and combined) calculated the same value among locations and genotypes variances but they exhibited different significant variations due to different values of tabulated $\mathrm{F}$ of them, which depends on degree of freedom of error.

The collected surpassed combined since it does not need to calculate homogeneity test of variances (Bartlett test) before the start of analysis and could estimate locations and genotypes variances using one column of each location.

\section{REFERENCES}

Abo Tour H. B., Seyam S. M. and Abd El Rahman L. M. (1996). Analytical study on the economic characters of new and commercial Egyptian cotton. Egypt. J. Agric. Res., 74 (3) : 781-791. 
Badr S.S. and El Sayed S. A. (2004). Evaluation of some long staple Egyptian cotton genotypes for yield, seed quality and seed viability characters. J. Agric. Res. Tanta Univ., 30 (2) : 304-326.

Bailey N. T. (1994). Statistical Methods in Biology. Third Ed. Cambridge University Press, Cambridge, England.

Cochran W.G. and Cox G. M. (1950). Experimental Designs. John Wiley and Sons, New York., U.S.A.

Federer W. T. (1955).Experimental Design. Theory and Application. The MacMilan Company New York, U.S.A.

Gomez K. A. and Gomez A. A. (1984). Statistical Procedures for Agricultural Research. John Wiley and Sones, New York, U.S.A.

Idris H.A. (2008). Evaluation of some Egyptian cotton genotypes in the first and the second picks by latin square design with a combined analysis. Bull. Fac. Agric. Cairo Univ., 59 (1): 13-23.
Little T.M. and Hills F. J. (1978). Agricultural Experimentation Design and Analysis. John Wiley and Sons, New York., U.S.A.

Rahoumah M.R., Abd El Bary A.M., Hamoud H.M. and Yehia W.M. (2008). Assessment of genetic diversity and stability for yield traits of some Egyptian long staple cotton genotypes. Egypt. J . Agric. Res., 86 (4) 1447- 1462.

Roger G.P. (1994).Agricultural Field Experiments Design and Analysis. Marcel Dekker, Inc. New York, U.S.A.

Sing P. and Narayanan S. S. (2000). Biometrical Techniques in Plant Breeding. Second Ed., Ludhiana, New Delhi, India.

Snedecor G. W. and Cochran W. G. (1967). Statistical methods. Iowa State Univ. Press, Ames, Iowa, U. S. A.

Steel R. G. and Torrie J. H. (1980). Principles and Procedures of Statistics. Second Edit., McGraw Hill Book Co. New York, U.S.A.

\section{تقييم بعض التراكيب الوراثية من القطن المصري فى الالتا باستخدام تصميم المربع اللاتيني المضغوط والمجمع حاتم أحمد إدريس - سعيد عبد الرازق الطحان - سامي سعد بلر$$
\text { معهد بحوث القطن - مركز البحوث الزراعية ــ الجيزة - مصر }
$$

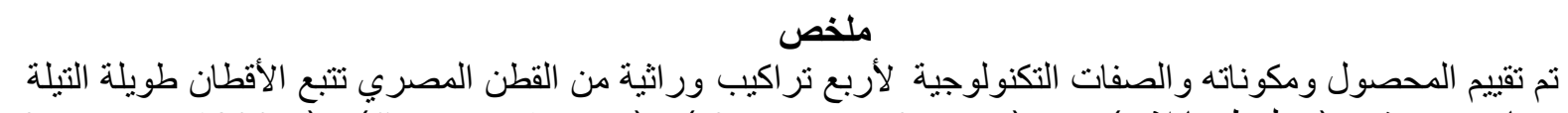

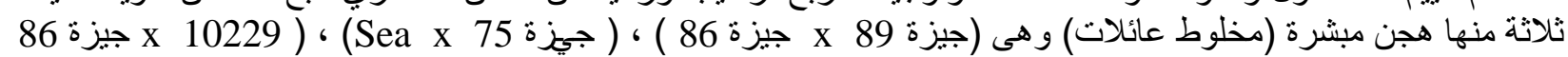

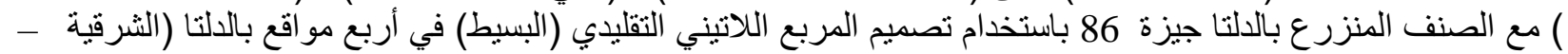

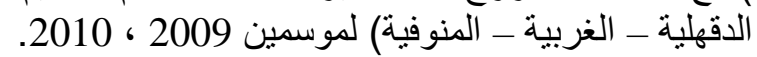
وقد تم إجر اء تحليلات إحصائية بطرق تقلية البيدية وأخرى مقترحة بهدف تقدير تباين المو اقع و التر اكيب الور اثية . أولا : التحليل البسيط (التقليدي)

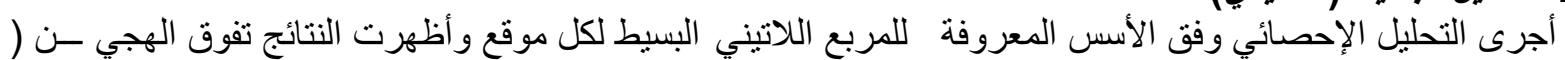

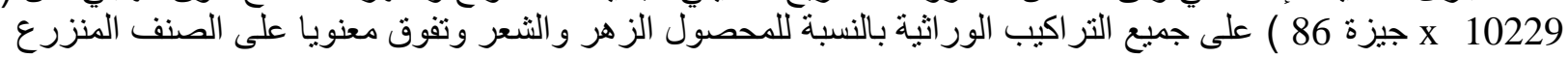
جيزة 86 في جميع المو اقع ما عدا الدقهية التية.

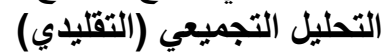

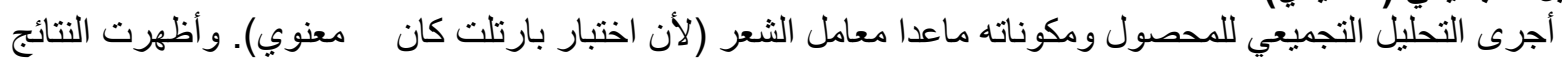

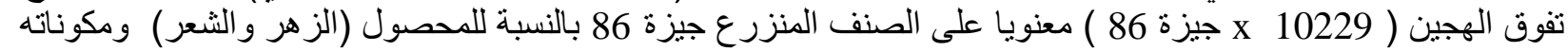

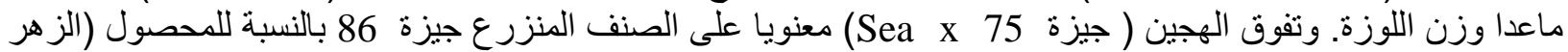
والثعر) فقط. التحليل المضغوط (مقترح)

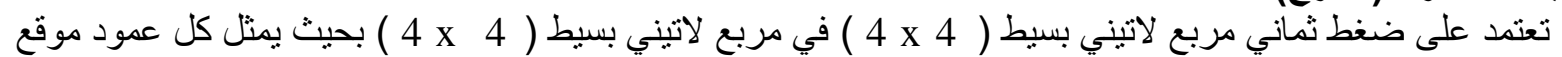

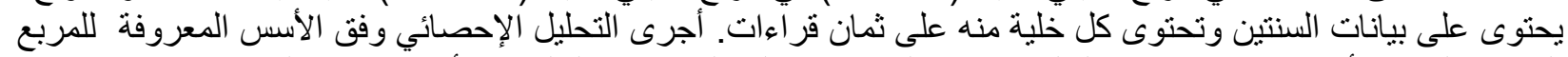

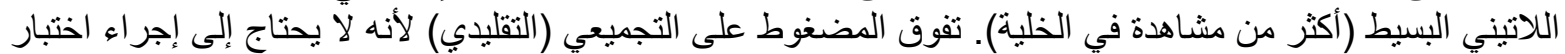

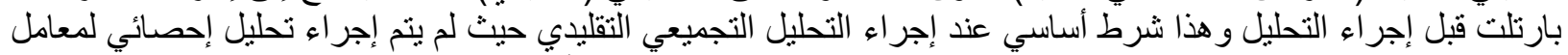

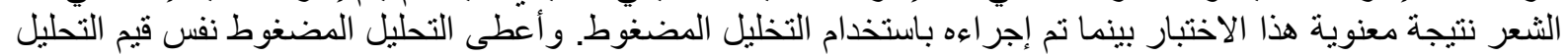

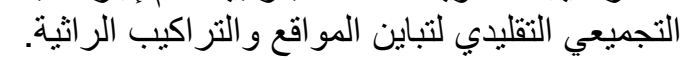

التحليل المجمع (مقترح) التئين 


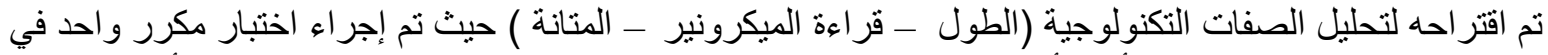

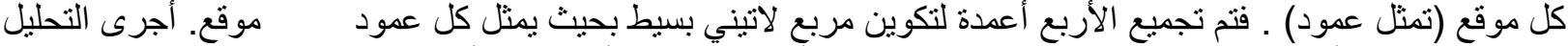

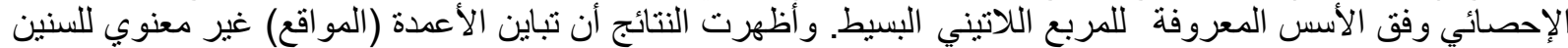

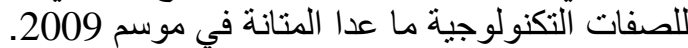

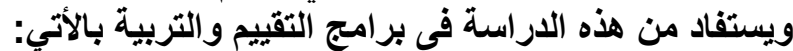

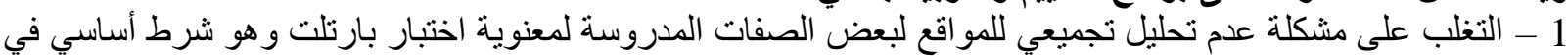

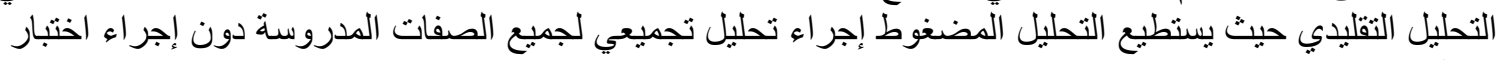
بارنتلت. 2- التغلب على مشكلة عدم تحليل تجميعي للمو اقع في حالة تمثيل الموقع بمكرر واحد حيث يستطيع التحليل المجمع تقدير

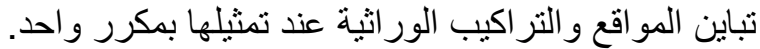

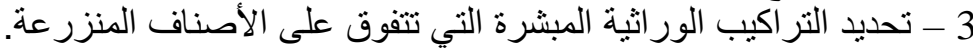

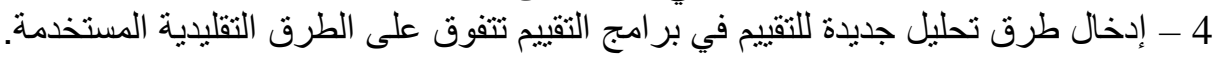

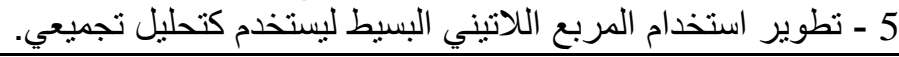

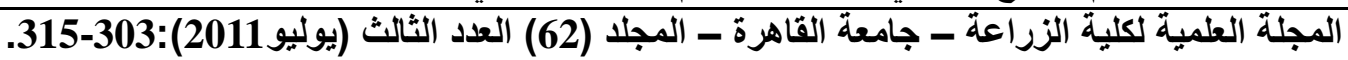

